\title{
Results of a 16-week safety assurance study with rats fed genetically modified Bt maize: effect on growth and health parameters
}

\author{
Beata Szymczyk ${ }^{1}$, Witold Szczurek ${ }^{1}$, Sylwester Świątkiewicz ${ }^{1}$, \\ Krzysztof Kwiatek ${ }^{2}$, Zbigniew Sieradzki², Małgorzata Mazur ${ }^{2}$, \\ Dariusz Bednarek ${ }^{3}$, Michał Reichert ${ }^{4}$ \\ ${ }^{1}$ Department of Nutrition Physiology, National Research Institute of Animal Production, 32-083 Balice, Poland \\ ${ }^{2}$ Department of Hygiene of Animal Feedingstuffs, \\ ${ }^{3}$ Department of Cattle and Sheep Diseases, \\ ${ }^{4}$ Department of Pathology, \\ National Veterinary Research Institute, 24-100 Pulawy, Poland \\ beata.szymczyk@izoo.krakow.pl
}

Received: April 19, 2018

Accepted: October 25, 2018

\begin{abstract}
Introduction: The influence of feeding genetically modified MON 810 hybrid maize on the growth and haematological and biochemical indices of rats was tested. Material and Methods: Two conventional (non-GM) and two test (MON 810) lines of maize were used in semi-purified diets at the level of $40 \% \mathrm{w} / \mathrm{w}$. The non-GM I, MON 810 I, non-GM II, and MON 810 II maize lines were near-isogenic. A total of 40 male 6 -week-old Wistar-derived rats were assigned to four equal feeding groups corresponding to the four maize lines for 16 weeks. Overall, health, body weight gain, clinical pathology parameters, gross changes, and appearance of tissues were compared between groups. Results: There were no statistically significant differences in the weight gain or relative organ weights of rats, but there were some non diet-related histopathological changes in the liver, kidneys, and spleen. Except for creatinine level, no diet-related effects were observed in haematology or most of the biochemical indices. Transgenic DNA of MON 810 maize was not detected in the tissues or faeces nor in the DNA of $E$. coli isolated from the rectum digesta of rats given transgenic feeds. In our experiment, various metabolic indices of rats fed non-GM diets or genetically modified (MON 810) maize for 16 weeks were similar. No adverse nutrition-related health effects were detected. Conclusion: MON 810 maize seems to be as safe as the conventional maize lines.
\end{abstract}

Keywords: rats, MON 810 maize, blood parameters, histopathology, transgenic DNA.

\section{Introduction}

Despite the undeniable benefits of using biotechnology for genetic modification of crops bred for human and animal consumption, the debate on genetically modified (GM) food grows in intensity. Objections to GM plants fix on various aspects, but in particular technical ones, concerning the construction of transgenes, abuse of constitutive promoters or lack of control over the insertion of a transgene into the genome structure (13). There are also concerns about the medical consequences, i.e. deleterious effects of GM crops on humans or animals. During the last few years, the objective of many studies was to determine the nutrient value of GM feeds compared to their conventional counterparts. The results available to date reveal no significant differences in the nutritional value of feedstuffs containing GM and non-GM varieties (7). They are also reassuring as to the safety of transgenic feed. One of the most widespread GM plants of the first generation is Bt (Bacillus thuringiensis) maize. This maize, the hybrid MON 810 grown in Europe has been genetically modified by the insertion of DNA sequences into the plasmid vector that encodes a modified Bacillus thuringiensis (subspecies kumamotoensis) soil bacterium Cry1 A(b) protein. This protein is selectively toxic to larvae of the European maize borer (Ostrinia numbilatis), the primary maize pest in Europe. Although there is a comprehensive set of studies that confirm the absence of unintended 
effects and the nutritional equivalence of MON 810 maize to existing conventional hybrids, animal feeding studies should also be undertaken to provide further assurance of nutritional safety and value. There were no adverse effects of transgenic maize (Bt and $\mathrm{Gt}$ ) on production indices, quality of pork $(3,23,24)$, or meat of broiler chickens and laying hens $(8,25,26,27)$ uncovered in previous work. The obtained data indicated that transgenic DNA sequences from $\mathrm{Bt}$ maize are well digested in the gastrointestinal tract and are not transferred to animal tissues. Moreover, the results of studies on model animals, although not entirely unambiguous, do not provide convincing evidence of the negative effects of genetically modified feed. Many long-term single-generation studies on rats fed GM plant feed have not demonstrated any negative effect of these plants on animal metabolism or health. Hammond et al. (10) fed rats with doses containing $11 \%$ or $33 \%$ of $\mathrm{Bt}$ maize grains for three months. The research did not show statistically significant differences in haematological or biochemical parameters of blood and urine analysis in relation to animals of the group provided with non-GM feed. Neither were adverse effects on the blood biochemical parameters found in rats fed diets with MON 88017 rootworm-resistant and glyphosate-tolerant maize (9, 10, 11). On the other hand, Kılıçgün et al. (15) observed differences in organ size and other parameters in rats fed a diet with GM maize versus a non-GM control diet. Also El-Shamei et al. (6) showed that GM maize intake influenced histopathological features in the liver, kidneys, testes, spleen, and small intestine in rats during the physiological process of ageing, although the mechanisms responsible for such alterations are still unknown. The authors suggested that further research should be carried out in order to clarify all doubts. Optimalisation and improvement of safety assessment methods will benefit crop developers, regulators, and other scientists as it will be shown that they not only demonstrate the safety of currently available GM products but also can readily be applied to newly developed GM crops as well. Therefore, the aim of our study was to test the possible influence of feeding two lines of genetically modified $\mathrm{Bt}$ maize on the growth and haematological and biochemical indices of rats.

\section{Material and Methods}

Animals and experimental diets. Casein (Lacpol, Poland) and two control non-genetically modified (NGM)) and two test MON 810 maize varieties were used as protein sources in semi-purified diets (Table 1). All the experimental diets were isoenergetic and isonitrogenous (compounded to supply $20 \%$ protein on dry basis) and contained non-modified or modified maize added in an amount of $40 \% \mathrm{w} / \mathrm{w}$. Test GM maize grain was obtained from plants containing the Bt geneexpressing Cry1A(b) protein (YieldGard/MON 810, Monsanto), genetically modified for protection against the European maize borer (Ostrinia numbilatis). According to the producer's declaration, the lines (cultivars) of non-GM I and GM I, and non-GM II and GM II maize were near-isogenic in the pair relationships (i.e. were lines of maize of comparable genetics but lacking or having the CrylA(b) sequences).

Table 1. Composition of experimental diets (\%)*

\begin{tabular}{|c|c|c|c|c|}
\hline \multirow{2}{*}{ Ingredient } & \multicolumn{4}{|c|}{ Treatment } \\
\hline & NGM I & MON $810 \mathrm{I}$ & NGM II & MON 810 II \\
\hline Maize (test materials) & 40 & 40 & 40 & 40 \\
\hline Casein $^{1}$ & 18.3 & 18.0 & 18.2 & 18.0 \\
\hline Sucrose & 20 & 20 & 20 & 20 \\
\hline Sunflower oil & 6 & 6 & 6 & 6 \\
\hline Cellulose $^{2}$ & 4 & 4 & 4 & 4 \\
\hline Mineral mixture ${ }^{3}$ & 4 & 4 & 4 & 4 \\
\hline Vitamin mixture $^{4}$ & 2 & 2 & 2 & 2 \\
\hline DL-methionine & 0.3 & 0.3 & 0.3 & 0.3 \\
\hline Maize starch & 5.4 & 5.7 & 5.5 & 5.7 \\
\hline \multicolumn{5}{|c|}{ Calculated nutrient content: } \\
\hline Crude protein & 192.5 & 192.3 & 192.4 & 192.5 \\
\hline Crude fat & 6.5 & 6.4 & 6.5 & 6.4 \\
\hline Crude fibre & 5.1 & 5.0 & 5.1 & 5.0 \\
\hline Methionine + Cystine & 9.8 & 9.7 & 9.8 & 9.7 \\
\hline
\end{tabular}

*Nutrient requirements of laboratory animals, NRC (1995)

${ }^{1}$ Protein $(\mathrm{N} \times 6.25)$ concentration: $85.79 \mathrm{~g} / 100 \mathrm{~g}$; dry matter: $88.9 \mathrm{~g} / 100 \mathrm{~g}$. The amount of dietary casein depended on the maize protein content

${ }^{2}$ Whatman CF11 (Sigma-Aldrich, Poland)

${ }^{3} 1 \mathrm{~kg}$ of mixture contained $\mathrm{CaCO}_{3} 12.4 \mathrm{~g}, \mathrm{KH}_{2} \mathrm{PO}_{4} 13.2 \mathrm{~g}, \mathrm{Ca}\left(\mathrm{H}_{2} \mathrm{PO}_{4}\right) 23 \mathrm{~g}, \mathrm{MgSO}_{4} \cdot 7 \mathrm{H}_{2} \mathrm{O} 4.2 \mathrm{~g}, \mathrm{NaCl} 6.7 \mathrm{~g}, \mathrm{MnSO}_{4} 4 \mathrm{H}_{2} \mathrm{O} 0.21$ $\mathrm{g}, \mathrm{ZnSO}_{4} 7 \mathrm{H}_{2} \mathrm{O} 0.025 \mathrm{~g}, \mathrm{FeSO}_{4} 7 \mathrm{H}_{2} \mathrm{O} 0.13 \mathrm{~g}, \mathrm{KJ} 0.032 \mathrm{~g}$, and $\mathrm{CuSO}_{4} 5 \mathrm{H}_{2} \mathrm{O} 0.098 \mathrm{~g}$

${ }_{4}^{4} \mathrm{~kg}$ of mixture contained: vitamin A 4375 I.U., vitamin $\mathrm{D}_{3} 1,750$ I.U., vitamin $\mathrm{B}_{1} 17.5 \mathrm{mg}$, vitamin $\mathrm{B}_{2} 35 \mathrm{mg}$, vitamin $\mathrm{B}_{6} 35$ $\mathrm{mg}$, vitamin $\mathrm{B}_{12} 33 \mu \mathrm{cg}$, biotin $0.8 \mathrm{mg}$, PABA $10 \mathrm{mg}$, nicotinamide $100 \mathrm{mg}$, panthothenic acid $35 \mathrm{mg}$, vitamin E $8.7 \mathrm{mg}$, and cholin chloride $1 \mathrm{~g}$ 
Seeds of all four maize lines were bought from Pioneer Hi-Bred Northern Europe Sales Division $\mathrm{GmbH}$, with authorisation from the European Commission Health and Consumers Directorate General. They have been approved for cultivation within the EU by individual decisions.

Forty male Wistar-derived rats from the Centre for Experimental Medicine of the Medical University of Silesia in Katowice (Poland) were used in the study and were approximately six weeks old at the start. The rats were housed individually in steel cages and had free access to the diets and water for the 16 weeks of the experiment. The animals were assigned to four equal experimental groups by stratified randomisation. Body mass and feed intakes were measured weekly. The testing facility provided appropriate environmental conditions $\left(23 \pm 2^{\circ} \mathrm{C}\right.$ room temperature, 12-h light/dark cycle, $40 \%-55 \%$ humidity).

Sampling procedure. At the end of the 16-week exposure, all the animals were euthanised and samples of blood, organs, and tissues were collected. Blood samples were collected into anticoagulant-filled tubes (EDTA) from the left ventricle of the heart. Immediately after the slaughter of the animals, their liver, kidneys, spleen, pancreas, duodenum, jejunum, and skeletal muscle samples were collected and fixed in $10 \%$ paraformaldehyde $(\mathrm{pH} 7)$.

Haematology. Blood samples were analysed by standard laboratory methods using an Auto Counter AC920 haematological analyser (Swelab Instrument, Sweden). The following morphological parameters were assayed: the number of red blood cells (RBC), haematocrit (HCT), mean cell volume (MVP), haemoglobin content (HGB), mean weight and concentration of haemoglobin ( $\mathrm{MCH}$ and $\mathrm{MCHC}$ ), number of platelets (PLT) and their mean volume (MVP), the total number of white blood cells (WBC), 3-fractional part of leukocytes to lymphocytes (LYM), medium-sized cells (MID - monocytes, eosinophils, and basophils in total), and neutrophils (PMNL). Lymphocytes, MID cells, and neutrophils were analysed both in relative (percentage) and absolute terms.

Serum chemistry. Blood samples for the biochemical parameters were collected into test tubes and centrifuged $(4,000 \mathrm{~g}, 10 \mathrm{~min})$ to obtain serum samples. The following parameters were determined: urea $\mathrm{N}$, cholesterol, aspartate aminotransferase (AST), alanine aminotransferase (ALT), alkaline phosphatase (ALP), creatinine, total bilirubin, and amylase. Serum biochemical parameters were measured by spectrometric methods using a Vitros chemistry analyser and Ektachem DT-60-II system with DT, DTE, and DTSC modules (all Ortho Clinical Diagnostics, USA).

DNA extraction. DNA was extracted from tissues and faeces with commercial extraction kits using CTAB methods (PN-EN ISO/IEC 21571:2007) which included an event-specific PCR for MON810 (170 bp PCR product), and from heparinised blood with a Blood Genomic AX extraction kit (A\&A Biotechnology, Poland), according to the manufacturer's instructions. PCR reactions were performed in $20 \mu \mathrm{L}$ mixtures (Applied Biosystems, USA) containing $1 \times$ buffer for PCR, $0.25 \mathrm{mM}$ of dNTP, $2.5 \mathrm{mM}$ of $\mathrm{MgCl}_{2}, \quad 0.5 \mu \mathrm{M}$ of forward and reverse primer, $0.025 \mathrm{U} / \mu \mathrm{L}$ of AmpliTaq Gold polymerase, and genomic DNA templates. For detection of maize MON810 gene sequences, the DNA was incubated in a Biometra T1 thermocycler (Biometra, Germany) under the following programme: 12 min denaturation at $95^{\circ} \mathrm{C}, 40$ cycles of $30 \mathrm{~s}$ at $95^{\circ} \mathrm{C}, 30 \mathrm{~s}$ at $64^{\circ} \mathrm{C}$, and $30 \mathrm{~s}$ at $72^{\circ} \mathrm{C}$, and a final extension step of $3 \mathrm{~min}$ at $72^{\circ} \mathrm{C}$. The PCR products were separated by electrophoresis on 2\% agarose gels (LE GQ Agarose, Fermentas, USA) using $1 \%$ buffer TBE containing ethidium bromide intercalating dye. The limit of detection of the PCR methods was five copies of the DNA fragment per reaction.

Pathology. After fixation, the tissue sections were processed by routine histological methods. Paraffin sections $(5 \mu \mathrm{m})$ were stained with haematoxylin and eosin (HE). Organs and tissues were examined by a board-certified veterinary pathologist.

Statistical analysis. The effects of feeding genetically modified $\mathrm{Bt}$ maize on the haematological and biochemical indices of rats were analysed using two-way ANOVA generated by the STATISTICA v. 12.0 package (StatSoft Inc., USA). The model assumptions of normality and homogeneity of variance were verified by the Shapiro-Wilk and Levene tests, respectively.

\section{Results}

Growth rates. Feeding rats diets containing genetically modified maize or only a conventional (native) maize component did not affect their growth rate or final body weight (Table 2). No statistically significant differences were also noted in the relative weight of their heart, liver, kidneys, or spleen ( $\mathrm{P} \geq 0.5)$.

Haematology. The erythrogram and leukogram of the rats are presented in Table 3. No significant differences in the haematological parameters were observed between rats in the control and experimental groups. The number of erythrocytes, their volume, content of haemoglobin, and leukocyte and platelet cell counts did not differ among the groups. Serum granulocyte, lymphocyte, and monocyte percentages were also similar in the rats fed diets with GM and diets with non-GM maize. The mean levels of all the haematological parameters were within the natural variation observed for Wistar rats at the age of 16-24 weeks. 
Table 2. Final body weights and the value of relative organ weights in rats

\begin{tabular}{|c|c|c|c|c|c|c|}
\hline \multicolumn{2}{|l|}{ Treatment } & \multirow{2}{*}{$\begin{array}{l}\text { Final body } \\
\text { weight } \\
\text { (g) }\end{array}$} & \multicolumn{4}{|c|}{ Organs weight ( $\%$ of body weight) } \\
\hline Line of maize & $\begin{array}{l}\text { Genetic } \\
\text { modification }\end{array}$ & & Heart & Liver & Kidney & Spleen \\
\hline Line I NGM & - & 465 & 0.29 & 4.08 & 0.70 & 0.20 \\
\hline Line I MON 810 & + & 459 & 0.27 & 3.98 & 0.62 & 0.21 \\
\hline Line II NGM & - & 459 & 0.28 & 3.94 & 0.66 & 0.21 \\
\hline \multirow[t]{2}{*}{ Line II MON 810} & + & 469 & 0.28 & 3.97 & 0.66 & 0.21 \\
\hline & & \multicolumn{5}{|c|}{ Main effect means } \\
\hline \multirow{2}{*}{ Line of maize (LM) } & I & 462 & 0.28 & 4.03 & 0.66 & 0.205 \\
\hline & II & 464 & 0.28 & 3.95 & 0.66 & 0.210 \\
\hline $\mathrm{P}$ value & & 0.793 & 0.147 & 0.791 & 0.058 & 0.670 \\
\hline \multirow{2}{*}{ Genetical modification (GM) } & - & 462 & 0.285 & 4.01 & 0.68 & 0.205 \\
\hline & + & 464 & 0.275 & 3.97 & 0.64 & 0.210 \\
\hline$P$ value & & 0.876 & 0.815 & 0.621 & 0.973 & 0.566 \\
\hline Pooled SEM & & 6.020 & 0.001 & 0.102 & 0.006 & 0.003 \\
\hline $\begin{array}{l}\text { Significance of interaction, } \\
\text { GM } \times \text { LM }, \quad P \text { value }\end{array}$ & & 0.610 & 0.083 & 0.640 & 0.091 & 0.782 \\
\hline
\end{tabular}

Table 3. Serum analysis values of rats - haematological indices

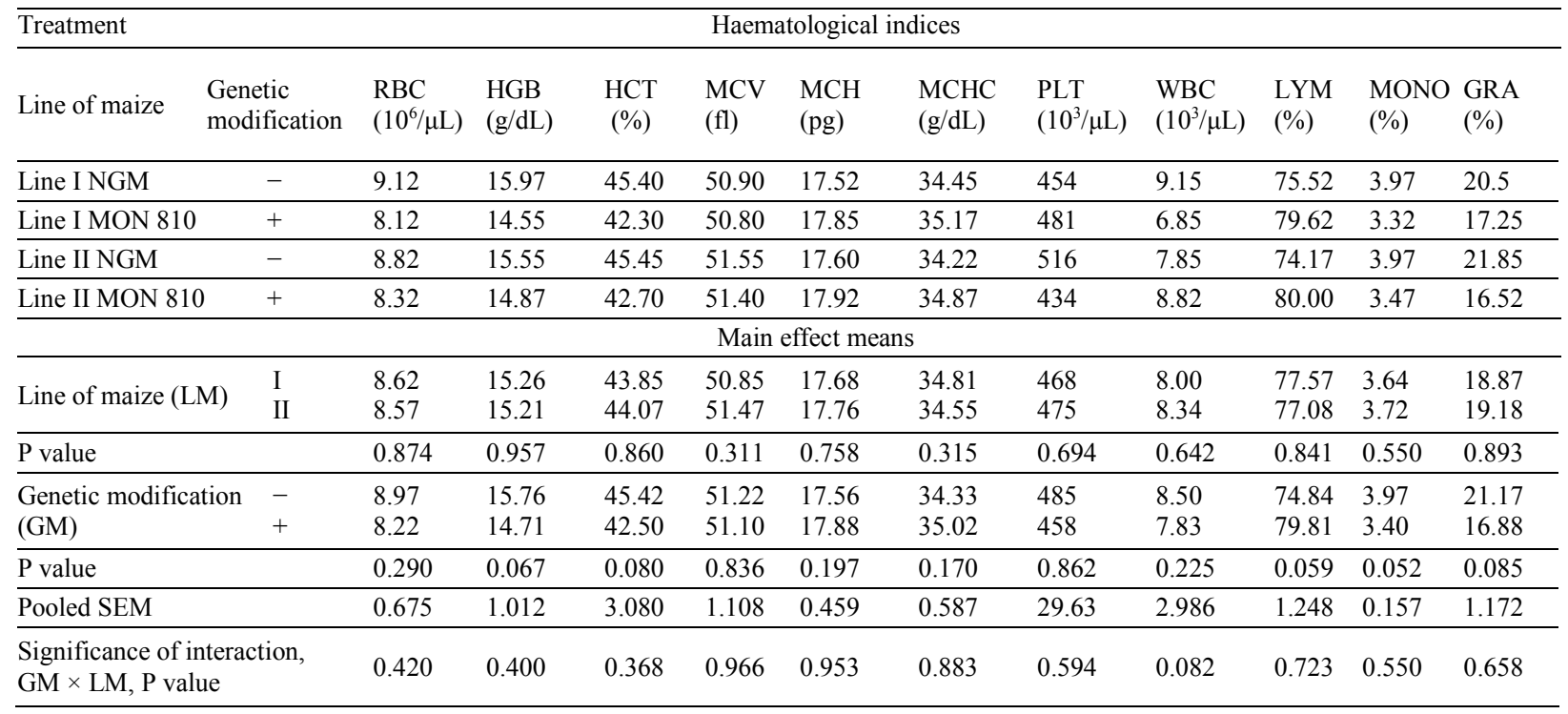

Table 4. Serum analysis values of rats - biochemical indices

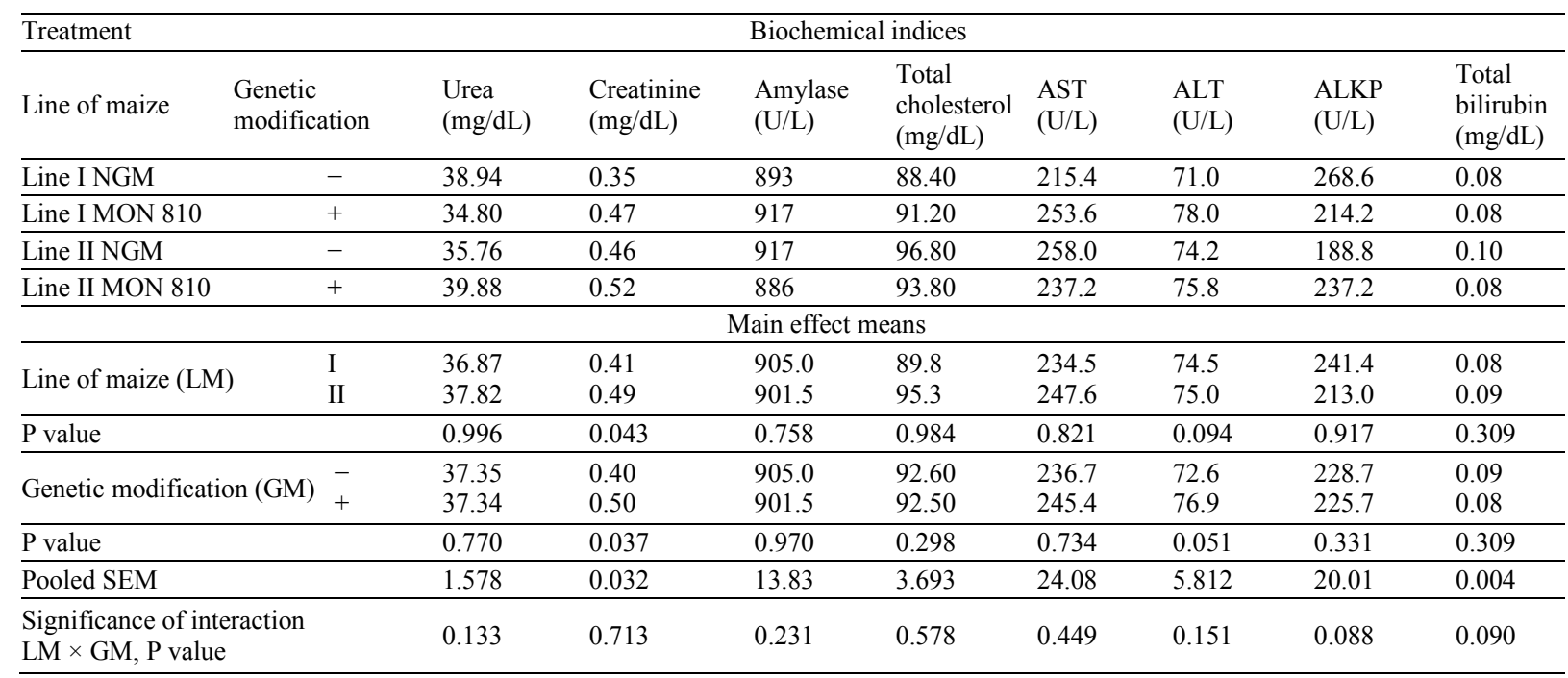


Biochemical blood serum analysis. The results of the biochemical analysis are given in Table 4 . The analysis of the blood biochemical parameters in most cases showed no significant effect of nutrition on the metabolism of the animals. There were no significant differences in aspartate aminotransferase (AST), alanine aminotransferase (ALT), or alkaline phosphatase (ALKP) in the blood of rats fed transgenic and traditional maize, and nor did the nutrition have any significant impact on the level of urea, amylase, total cholesterol, or total bilirubin. Creatinine levels differed depending on the line and genetic modification of maize $(\mathrm{P}<0.05)$, but they were within the range of reference values for adult rats.

Histopathological assays. Macroscopical and histopathological examinations showed no difference between control (diets with two non-GM maize lines) and experimental groups (diets with maize MON 810). Histopathological changes were observed in all the samples of the liver (a foamy structure of hepatocytes, moderate congestion of parenchyma, and areas of hepatocytes with vacuolated cytoplasm), and in all the preparations of the kidneys and spleen (small or moderate congestion of parenchyma). The changes were found in a similar range in both groups, regardless of allotment of the diet of GM or of NGM feed materials. The pancreas, duodenum, and skeletal muscles did not show any histopathological lesions.

Examination of transgenic DNA in organs and tissues. The analysis of samples of blood, kidneys, liver, muscles, faeces, and DNA of Escherichia coli isolated from the colon derived both from the rats fed a diet including transgenic maize and from their counterparts given conventional maize revealed that the presence of $\mathrm{Bt}$ transgenes characteristic for MON 810 maize was observed in none of the samples.

\section{Discussion}

Despite a number of studies which demonstrated no effect of genetically modified plants on animal health, the claim of the safety of this feed is still controversial in many countries. Therefore, for the public acceptance of these GM materials, safety assessments of new GMO feed products should be performed. The aim of this study was to evaluate the safety of GM feed based on observation of the health of rats fed diets containing conventional or genetically modified Bt maize.

Feeding rats diets containing genetically modified or conventional (native) maize did not affect the final body weight or growth of the animals. These findings are confirmed by the results obtained by Kosieradzka et al. (16) who did not find significant differences in the relative weights of some internal organs of rats fed diets with a $10 \%$ addition of dried genetically modified potato. Kılıç and Akay (14) also noted no differences in the relative weights of the liver or kidneys of F3 generation male between groups fed without the addition of maize (control) and groups fed with addition of conventional and genetically modified maize $(\mathrm{Bt})$. In these studies, the authors did observe significantly lower weights of some livers. Those of females fed a diet with added maize were lighter than those of females fed a diet containing no maize. But there were no differences between the groups receiving the conventional maize and the $\mathrm{Bt}$ maize. Hammond et al. (10) in a 90-day study revealed no significant differences in the growth of rats or the relative weights of some internal organs. Similar results were obtained by Chen $e t$ al. (4) in rats fed rice with an introduced gene for a trypsin inhibitor derived from cowpea (Vigna sinensis). In contrast, Kılıçuün et al. (15) observed an adverse effect of GM maize on organ size in rats fed a diet with GM maize versus a non-GM control diet. The length, height, and weight of the liver, spleen, and kidneys, and the length and weight of the lungs in $\mathrm{Bt}$ maize group rats were significantly different from these values for rats which ate conventional maize and control.

Our results for the haematological indicators fell within the physiological range, and no significant differences in the blood parameters were observed between rats in the control NGM groups and GM experimental groups. In a 13-week safety assurance study by Healy et al. (11), there were no adverse, testarticle-related effects on haematology parameters in rats fed glyphosate-tolerant MON 88017 maize. Similarly, in a subchronic feeding study of herbicidetolerant maize DP-098140-6 in Sprague-Dawley rats, no statistically significant or diet-related differences were obtained in mean haematology response variables for male or female rats in either of the test groups compared with the control animals (1). In an earlier 90-day safety assurance study with rats fed borerprotected maize, there were also no test article related changes in haematology parameters for the MON 810 maize fed animals (10). A series of Polish studies led the author to conclude that dietary GM maize did not affect the haematological parameters of pigs (23), Japanese quails (21), broiler chickens, or laying hens $(25,26)$. In the present investigation, blood creatinine concentration increased significantly in rats fed the GM diets. Significantly lower plasma levels of creatinine in groups fed diets containing non-GMO maize may relate to an anomaly in muscle function (14), but we did not observe any abnormal situation during the study. Higher levels of urea and a reduction in the concentration of protein in the blood of rats fed a diet with the addition of $\mathrm{Bt}$ rice were the findings of Schroder et al. (22) during 90 days of research. However, according to Kılıç and Akya (14), there were no significant differences in most of the biochemical parameters, including urea and creatinine, in the blood of rats sustained with Bt maize in relation to those of the group provided with conventional maize and the group given feed without maize. However, the authors 
observed sex-dependent differences in the rat plasma creatinine: in the group which received conventional maize that of the females was significantly higher than in the other experimental groups. In addition, de Vendômois et al. (29) found significant differences in the functioning of the kidneys, expressed by an increase in blood creatinine of male rats fed maize NK 603 and MON 863. In contrast, in other studies, where transgenic or conventional potatoes were added to the diet of rats, feeding these to the subjects did not affect the majority of blood biochemical parameters $(16,17)$. In the animals which ingested GM potatoes, there were only higher levels of iron, but these differences were not statistically significant. No adverse effects on the blood biochemical parameters were found in rats fed diets with MON 88017 rootworm-resistant and glyphosate-tolerant maize $(9,10,11)$.

In the present work, there were no significant differences in the serum activity of the liver enzymes ALT, AST or ALKP of rats fed GM and rats fed traditional maize, and our results confirm the findings of many earlier experiments. Raju et al. (20) studied three liver enzymes ( $\gamma$-glutamyl transferase, ALT, and AST) in a pertinent chicken maize feed experiment and found that none of the enzymes showed any significant level differences between the control or GM maize-fed chickens. Flachowsky et al. (7) reported that a high dietary level of GM Bt 176 maize had no statistically significant effect on the health status of 10 generations of quails. In contrast, in the study of Oraby et al. (18), biochemical analysis of AST and ALT revealed significant variations between the control and GM maize-fed rats. In other studies, significantly higher plasma activity of ALT in female rats fed GM rice (19) was found.

In this study histopathological changes were observed in all samples of the liver and in all preparations of the kidneys and spleen. The changes were found in a similar range in both groups, regardless of the diet's content or freedom from GM feed material. The observed foamy structure of hepatocytes was probably an artefact specific to the liver and associated with leached glycogen, hydrolysed during histological processing of the tissue sections. Likewise, in a 90-day safety assurance study with rats fed a diet containing borer-protected corn, no gross or microscopic lesions in rat organs (heart, kidneys, liver, pancreas, and thyroid) were observed that could be diet related. The few spontaneous lesions observed were of minimal to mild in severity and were randomly distributed among all groups (10). In another 90-day study, the kidneys of rats fed diets containing rootworm-protected maize (MON 863) were normal and comparable in appearance and function to the kidneys of control animals (9). Similarly, there was no evidence of increased incidence or severity of microscopic findings in the tissues of male or female rats in the herbicide-tolerant maize DP-098140-6 test group compared with rats in the control group (1). In contrast, in the study of Kılıç and Akya (14) markedly severe granular degeneration in the liver was seen in rats fed a Bt diet but not in the control and reference groups. However, different levels of minimal granular degradation were seen in all experimental groups. El-Shamei et al. (6) also showed that GM maize intake induced histopathological changes in the liver, kidneys, testes, spleen, and small intestine in rats during the physiological process of ageing, although the mechanisms responsible for such alterations are still unknown.

To date no evidence has appeared that demonstrates DNA absorbed by vertebrates via intestinal mucosa can be incorporated into the vertebrate genome $(25,26)$. In our study, transgenic DNA of Bt maize was not detected in the blood, liver, spleen, muscles or faeces, and nor was it in the DNA of $E$. coli isolated from the rectum digesta of rats fed transgenic feeds. The results of recent studies $(13,30)$ indicate a considerable degradation of endogenous genomic DNA. In model experiments with mice fed GM triticale (2) or rats fed GM cucumber (17), GM triticale transgenic DNA was not detected in intestinal content, faeces, blood, kidneys, liver, spleen, or muscles. Moreover, in the studies on laying hens (25) and pigs (24), no transgenic DNA was found in the liver, lungs, spleen, or muscles. Data corresponding to the results of these experiments were obtained by Jennings et al. (12) who reported that no small-sized fragments of transgenic (211 bp) or endogenous (213 bp) DNA were detected in the breast muscle of chickens fed a diet containing Bt (MON 810) maize. Transgenic DNA was also not found in tissues of rabbits fed diets containing GM maize or soybean meal (28).

In our experiment the results obtained for different metabolic indices of rats fed diets with conventional (control) or genetically modified (MON 810) lines of maize for a 16-week experiment were similar. No adverse nutrition-related health effects were detected. Thus, tested MON 810 maize lines seem to be as safe as their conventional equivalents.

Conflict of Interests Statement: The authors declare that there is no conflict of interests regarding the publication of this article.

Financial Disclosure Statement: This study was financed by Multiannual Project No. 03-17-35-09 funded by the Polish Ministry of Agriculture and Rural Development for beneficiaries including the National Research Institute of Animal Production, Balice, Poland.

Animal Rights Statement: The experiments on animals were conducted in accordance with the Local Ethical Committee in Krakow (Poland) laws and regulations as regards care of animals. 


\section{References}

1. Appenzeller L.M., Munley S.M., Hoban D., Sykes G.P., Malley L.A., Delaney B.: Subchronic feeding study of grain from herbicide-tolerant maize DP-O9814O-6 in Sprague-Dawley rats. Food Chem Toxicol 2009, 47, 2269-2280.

2. Baranowski A., Rosochacki S., Parada R., Jaszczak K., Zimny J., Połoszynowicz J.: The effect of diet containing genetically modified triticale on growth and transgenic DNA fate in selected tissues of mice. Animal Sci Papers Rep 2006, 24, 129-142.

3. Bednarek D., Dudek K., Kwiatek K., Świątkiewicz M., Świątkiewicz S., Strzetelski J.: Effect of a diet composed of genetically modified feed components on the selected immune parameters in pigs, cattle, and poultry. Bull Vet Inst Pulawy 2013, 57, 209-2017. doi:10.2478/bvip-2013-0038.

4. Chen X., Zhuo Q., Piao J., Yang X.: Immunotoxicologic assessment of transgenic rice. J Hyg Res 2004, 33, 770-780.

5. Czerwiński J., Bogacki M., Jalali B.M., Konieczka P., Smulikowska S.: The use of genetically modified Roundup Ready soyabean meal and genetically modified MON 810 maize in broiler chicken diets. Part 1. Effects on performance and blood lymphocyte subpopulations. J Anim Feed Sci 2015, 24, 134-143.

6. El-Shamei Z.S., Gab-Alla A.A., Shatta A.A., Moussa E.A. Rayan A.M.: Histopathological changes in some organs of male rats fed on genetically modified corn (Ajeeb YG). J Am Sci 2012, 8, 684-696.

7. Flachowsky G., Chesson A., Aulrich K.: Animal nutrition with feeds from genetically modified plants. Arch Anim Nutr 2005, $59,1,1-40$.

8. Halle I., Aulrich K., Flachowsky G.: Four generations of feeding of GMO-corn to breeder quail. (Fütterung von gentechnisch verändertem Mais an Zuchtwachtein über vier Generationen). Proc Soc Nutr Physiol 2004, 13, 124.

9. Hammond B.G., Dudek R., Lemen J., Nemeth M.A., Results of a 13 week safety assurance study with rats fed grain from glyphosate tolerant maize. Food Chem Toxicol 2004, 42, 1003-1014.

10. Hammond B.G., Lemon J., Dudek R., Ward D., Jiang C., Nemeth M.A., Burns J.: Results of a 90-day safety assurance study with rats fed grain from maize rootworm - protected maize. Food Chem Toxicol 2006, 44, 147-160.

11. Healy C., Hammond B., Kirkpatrick J.: Results of a 13-week safety assurance study with rats fed grain from corn rootwormprotected, glyphosate-tolerant MON 88017 corn. Food Chem Toxicol 2008, 46, 2517-2524.

12. Jennings J.C., Albee L.D., Kolwyck D.C., Surber J.B., Taylor M.L., Hartnell G.F., Lirette R.P., Glenn K.C. Attempts to detect transgenic and endogenous plant DNA and transgenic protein in muscle from broilers fed YieldGard corn borer corn. Poultry Sci 2003, 82, 371-380.

13. Kharazmi M., Bauer T., Hammes W., Hertel C.: Effect of food processing on the fate of DNA with regard to degradation and transformation capability in Bacillus subtilis. Syst Appl Microbiol 2003, 26, 495-501.

14. Kılıç A., Akay T.: A three generation study with genetically modified Bt maize in rats, biochemical and histopathological investigation. Food Chem Toxicol 2007, 46, 1164-1170.

15. Kılıçgün H., Gursul C., Sunar M., Gökşen, G.: The comparative effects of genetically modified maize and conventional maize on rats. J Clin Anal Med 2013, 4, 136-139.

16. Kosieradzka I., Sawosz E., Szopa J., Bielecki W.: Potato genetically modified by 14-3-3 protein repression in growing rat diets. Part II. Health status of experimental animals. Pol J Food Nutr Sci 2008, 58, 377-382.
17. Kosieradzka I., Vasko V., Szwacka M., Przybysz A., Fiedorowicz Sz: Evaluation of the possibility of horizontal gene transfer accumulation of transgenic DNA from the diet in the bodies of rats. J Anim Feed Sci 2010, 19, 307-315.

18. Oraby H., Kandil M., Shaffie N., Ghaly I.: Biological impact of feeding rats with a genetically modified-based diet. Turk J Biol 2015, 39, 265-275.

19. Poulsen M., Kroghsbo S., Schrøder M., Wilcks A., Jacobsen H., Miller A., Frenzel T., Danier J., Rychlik M., Shu Q.: A 90-day safety study in Wistar rats fed genetically modified rice expressing snowdrop lectin Galanthus nivalis (GNA). Food Chem Toxicol 2007, 3, 350-363.

20. Raju M.V.L.N., Rama Rao S.V., Radhika K., Panda A.K.: Effect of amount and source of supplemental dietary vegetable oil on broiler chickens exposed to aflatoxicosis. Brit Poultry Sci 2005, 46, 587-594.

21. Sartowska K.E., Korwin-Kossakowska A., Seder G.: Genetically modified crops in a 10-generation feeding trial on Japanese quails. Evaluation of its influence on birds' performance and body composition. Poult Sci 2015, 12, 2909-2916.

22. Schroder M., Poulsen M., Wilcks A., Kroghsbo S., Miller A., Frenzel T., Danier J., Rychlik M., Emami K., Gatehouse A., Shu Q., Engel K.H., Altosaar I., Knudsen I.: A 90-day safety study of genetically modified rice expressing Cry $1 \mathrm{Ab}$ protein (Bacillus thuringensis toxin) in Wistar rats. Food Chem Toxicol 2007, 45, 339-349.

23. Świątkiewicz M., Bednarek D., Markowski J., Hanczakowska E., Kwiatek K.: Effect of feeding genetically modified maize and soybean meal to sows on their reproductive traits, haematological indices and offspring performance. Bull Vet Inst Pulawy 2013, 57, 413-418.

24. Świątkiewicz M., Hanczakowska E., Twardowska M., Mazur M., Kwiatek K., Kozaczyński W., Świątkiewicz S., Sieradzki M.: Effect of genetically modified feeds on fattening results and transfer of transgenic DNA to swine tissues. Bull Vet Inst Pulawy 2011, 55, 121-125.

25. Świątkiewicz S., Koreleski J., Arczewska-Włosek A., Świątkiewicz M., Twardowska M., Markowski J., Mazur M., Sieradzki Z., Kwiatek K.: Detection of transgenic DNA from Bt maize and herbicide tolerant soybean meal in tissues, eggs, and digestive tract content of laying hens fed diets containing genetically modified plants. Ann Anim Sci 2011, 11, 1, 413-424.

26. Świątkiewicz S., Twardowska M., Markowski J., Mazur M., Sieradzki Z., Kwiatek K.: Fate of transgenic DNA From Bt Maize and Roundup Ready Soybean meal in broilers fed GMO feed. Bull Vet Inst Pulawy 2010, 54, 237-242.

27. Taylor M.L., Stanisiewski E.P., Riordan S.G., Nemeth M.A., George B., Hartnell G.F.: Comparison of broiler performance when fed diets containing Roundup Ready (event RT73, nontransgenic control, or commercial canola meal. Poultry Sci 2004, 83, 456-461.

28. Tudisco R., Lombardi P., Bovera F., d Angelo D., Cutrignelli M.I., Mastellone V., Terzi V., Avallone L., Infascelli F.: Genetically modified soya bean in rabbit feeding, detection of DNA fragments and evaluation of metabolic effects by enzymatic analysis. Anim Sci 2006, 82, 193-199.

29. de Vendômois S.F., Roullier F., Cellier D., Séralini G.E.: A comparison of the effects of three GM corn varieties on mammalian health. Int J Biol Sci 2009, 5, 706-726.

30. Weiss J., Ros-Chumillas M., Pena L., Egea-Cortines M.: Effect of storage and processing on plasmid, yeast and plant genomic DNA stability in juice from genetically modified oranges. J Biotechnol 2007, 128, 194-199. 